Article

\title{
Photoacoustic/Ultrasound/Optical Coherence Tomography Evaluation of Melanoma Lesion and Healthy Skin in a Swine Model
}

\author{
Karl Kratkiewicz ${ }^{1}$, Rayyan Manwar ${ }^{1}\left(\mathbb{D}\right.$, Ali Rajabi-Estarabadi ${ }^{2}(\mathbb{D}$, \\ Joseph Fakhoury $^{3}$, Jurgita Meiliute ${ }^{4}$, Steven Daveluy ${ }^{5,6}$, Darius Mehregan ${ }^{3}$ \\ and Kamran (Mohammad) Avanaki 1,3,5,6,*(D) \\ 1 Department of Biomedical Engineering, Wayne State University, Detroit, MI 48201, USA; \\ karl.kratkiewicz@wayne.edu (K.K.); r.manwar@wayne.edu (R.M.) \\ 2 Dr. Phillip Frost Department of Dermatology and Cutaneous Surgery, University of Miami Miller School of \\ Medicine, Miami, FL 33136, USA; arajabi@med.miami.edu \\ 3 Wayne State University School of Medicine, Detroit, MI 48201, USA; jfakhour@med.wayne.edu (J.F.); \\ dmehregan@wayne.edu (D.M.) \\ 4 EKSPLA USA, Bozeman, MT 59715, USA; jurgita@altosphotonics.com \\ 5 Department of Neurology, Wayne State University School of Medicine, Detroit, MI 48201, USA; \\ sdaveluy@med.wayne.edu \\ 6 Barbara Ann Karmanos Cancer Institute, Detroit, MI 48201, USA \\ * Correspondence: mrn.avanaki@wayne.edu; Tel.: +1-313-577-0703
}

Received: 26 April 2019; Accepted: 16 June 2019; Published: 24 June 2019

check for updates

\begin{abstract}
The marked increase in the incidence of melanoma coupled with the rapid drop in the survival rate after metastasis has promoted the investigation into improved diagnostic methods for melanoma. High-frequency ultrasound (US), optical coherence tomography (OCT), and photoacoustic imaging (PAI) are three potential modalities that can assist a dermatologist by providing extra information beyond dermoscopic features. In this study, we imaged a swine model with spontaneous melanoma using these modalities and compared the images with images of nearby healthy skin. Histology images were used for validation.
\end{abstract}

Keywords: photoacoustic imaging; cancer imaging; skin imaging; ultrasound; optical coherence tomography; melanoma; swine melanoma model

\section{Introduction}

Melanoma is the most dangerous form of skin cancer. Every year about 100,000 new cases of melanoma are diagnosed in the United States [1]. This incidence is doubled every 10 years [2]. In recent years, due to climate change, the incidence of melanoma has increased markedly, especially in fair-skinned populations [3]. The lifetime risk of developing melanoma for persons born in the year 2014 is 1 in 50 [4]. The survival rate from melanoma is about 98\% before metastasis, but drops to about $20 \%$ with distant metastasis [4]. Thus, early detection of melanoma is critical to preventing mortality.

Lesions suspicious for melanoma should undergo excisional biopsy; however, performing a biopsy creates pain, scarring, and disfigurements [5-7]. Biopsy also creates anxiety for the patients while they are waiting for the histopathology results. Partial (incisional) biopsies can lead to sampling error and inaccurate assessment of the lesion [8]. Thus, a non-invasive imaging technique that could discern melanoma from healthy tissue while visualizing tumor depth in real-time would allow for accurate diagnosis and surgical planning. 
Numerous non-invasive imaging modalities are under investigation to aid in the early detection of melanoma (Table 1). High-frequency ultrasound (US) can measure melanoma depth, but the image contrast is poor due to the small difference in the acoustic impedance between melanoma and the surrounding tissues [9-12]. Optical methods, such as confocal microscopy (CM) [13] and optical coherence tomography (OCT) [14-23], employ the scattering coefficient as a contrast to facilitate melanoma detection, but the penetration depth is limited. Other methods include multispectral imaging (MSI) [24-26], hyperspectral imaging (HSI) [27-29], Raman spectroscopy (RS) [30-32], and electrical impedance imaging (EI) [33-35]. There are other methods to study skin that have not been fully explored, such as the one in [36].

Table 1. Limitations of non-invasive melanoma imaging methods.

\begin{tabular}{cll}
\hline Imaging Modality & \multicolumn{1}{c}{ Limitation } & \multicolumn{1}{c}{ Clinical Problem } \\
\hline Dermoscopy (D) [37-39] & $\begin{array}{l}\text { Depends on appearance of classic } \\
\text { dermoscopic features. } \\
\text { Requires training to provide advantage } \\
\text { over clinical examination }\end{array}$ & $\begin{array}{l}\text { Failure to recognize melanomas } \\
\text { that lack specific dermoscopic } \\
\text { criteria }\end{array}$ \\
\hline $\begin{array}{c}\text { Multispectral imaging } \\
\text { (MSI) [24-26] }\end{array}$ & Data is projected onto the same plane & $\begin{array}{l}\text { Obscures depth information of } \\
\text { melanoma }\end{array}$ \\
\hline $\begin{array}{c}\text { Reflectance confocal } \\
\text { microscopy (RCM) [40-42] }\end{array}$ & $\begin{array}{l}\text { Limited field of view and penetration } \\
\text { depth }\end{array}$ & $\begin{array}{l}\text { Unable to determine depth of } \\
\text { invasion }\end{array}$ \\
\hline $\begin{array}{c}\text { High-frequency ultrasound } \\
\text { (HFS) [9-12] }\end{array}$ & Low specificity & $\begin{array}{l}\text { Inability to diagnose type of } \\
\text { tumor }\end{array}$ \\
\hline $\begin{array}{c}\text { Raman spectroscopy (RS) } \\
\text { [30-32] }\end{array}$ & $\begin{array}{l}\text { Analysis of chemical composition of } \\
\text { melanoma }\end{array}$ & $\begin{array}{l}\text { Lacks depth discrimination } \\
\text { similar to multispectral imaging }\end{array}$ \\
\hline $\begin{array}{c}\text { Electrical impedance } \\
\text { imaging (EI) [33-35] }\end{array}$ & $\begin{array}{l}\text { Analysis of electrical impedance spectrum } \\
\text { of lesion }\end{array}$ & $\begin{array}{l}\text { Cannot distinguish nevi from } \\
\text { melanoma }\end{array}$ \\
\hline $\begin{array}{c}\text { Optical coherence } \\
\text { tomography (OCT) [14-17] }\end{array}$ & Limited penetration depth & $\begin{array}{l}\text { Unable to determine depth of } \\
\text { invasion }\end{array}$ \\
\hline
\end{tabular}

Photoacoustic (PA) tomography is a non-invasive, non-ionizing, and functional imaging technique that can be used at the microscopic (photoacoustic microscopy (PAM)) [43-45] or macroscopic (photoacoustic computed tomography (PACT)) scales [46-51]. This kind of imaging combines the contrast of optical imaging with the spatial resolution of ultrasound. A nanosecond pulsed laser deposits energy onto a light-absorbing sample (such as the skin), causing a local temperature to increase, with subsequent thermal expansion through the thermoacoustic effect [52-56]. The thermal expansion yields a localized pressure increase, resulting in the formation of ultrasound waves that are detected by an ultrasound transducer to produce an image [57-60]. Various ultrasound transducer configurations can be designed for optimal imaging of the specified target $[46,61-67]$. This can be utilized to distinguish specific markers between healthy and melanoma tissue, as seen in Figure 1 . The limitations of the other techniques provided in Table 1 can be solved through the use of a combined US/PA system to discern structural information, provided by US, with molecular information, provided by PA. For example, the sensitivity to hemoglobin may be used to image angiogenesis in the growing tumor [68]. PA has previously been studied in cutaneous melanoma [69-74], demonstrating its ability to delineate melanoma tumor depth in animal models [69] and humans [70]. Currently, the differences between melanoma and healthy skin on large animals with spontaneous melanoma using photoacoustic imaging have not been elucidated. 


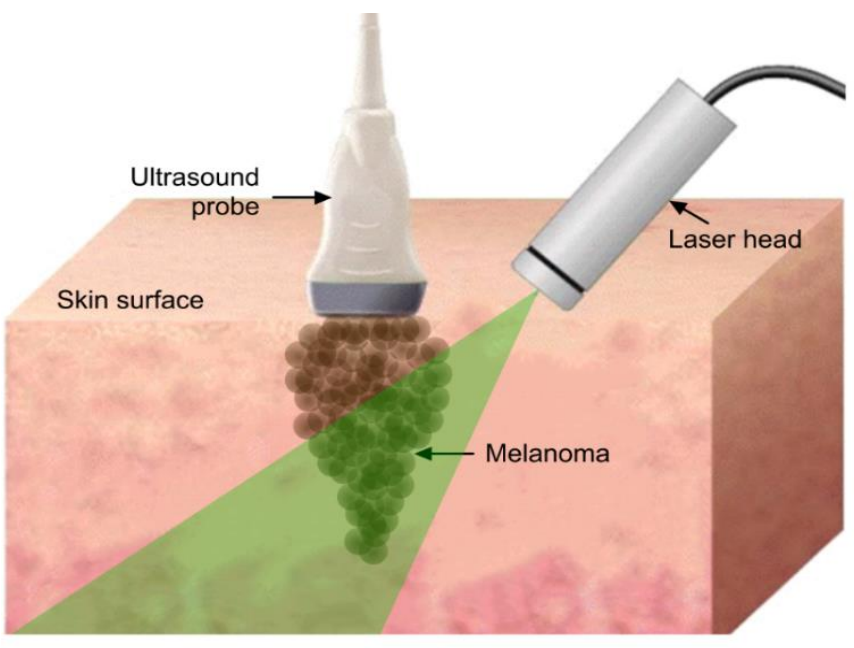

(a)

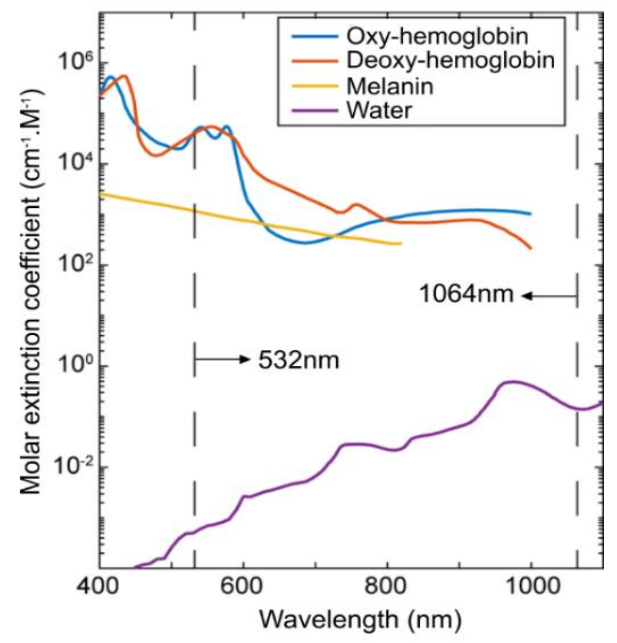

(b)

Figure 1. Principle of photoacoustic imaging. (a) Schematic of photoacoustic imaging setup for the acquisition of images from swine skin. (b) Optical absorption spectrum for most abundant photoacoustic absorbers in the skin with dashed lines showing wavelengths used in this study. Left: $532 \mathrm{~nm}$; right: $1064 \mathrm{~nm}$.

\section{Materials and Methods}

We developed a US/PA imaging system comprising a Vantage 128 system (Verasonics, inc., Kirkland, WA, USA) with attached L22-14v ultrasound transducer (Philips, Amsterdam, Netherlands). The transducer has a central frequency of $18.5 \mathrm{MHz}$ with $65 \%$ bandwidth, making a resolution of the order of $\sim 200 \mu \mathrm{m}$. The data acquisition was triggered by a Q-switched Nd:YAG laser (NL231-50-SH, EKSPLA, Vilnius, Lithuania) that was used to illuminate the skin tissue. Upon opening of the laser Q-switch, a trigger was sent to the Verasonics system to initiate the receive mode of the transducer for photoacoustic pressure wave detection. A novel bifurcated fiber bundle was manufactured by Fiberoptics Technology inc., Pomfret, CT, USA, and attached in a 3D-printed housing for homogeneous illumination of the imaging plane as seen in Figure 2. The laser energy was controlled with an attenuator to confirm the maximum energy deposited to be below the American National Standards Institute (ANSI) limits of $20 \mathrm{~mJ} / \mathrm{cm}^{2}$ for $532 \mathrm{~nm}$ and $100 \mathrm{~mJ} / \mathrm{cm}^{2}$ for $1064 \mathrm{~nm}$ [75]. The user interface was coded in the MATLAB software. In between photoacoustic frames, the script prompted a frame of ultrasound as well as for simultaneous US and PA image capture $[57,59,60]$. The components of the US/PA system can be seen in Figure 2.

The OCT system used in this study (Figure 2a) was a multi-beam, Fourier-domain, swept-source OCT (Vivosight, Michelson Diagnostic TM Inc., Kent, UK) with a central wavelength of $1305 \pm 15 \mathrm{~nm}$. The lateral and axial resolution of our system was $7.5 \mu \mathrm{m}$ and $10 \mu \mathrm{m}$, respectively. The 10-kHz sweep rate determined the time to generate one reflectivity profile. The penetration depth of the system was measured as $1.5 \mathrm{~mm}$ in healthy human skin [76]. This OCT system was based on multi-beam technology, similar to the technology used in dynamic focus OCT [77], in which four $0.25 \mathrm{~mm}$ wide consecutive confocal gates were combined to provide a total confocal gate of $1 \mathrm{~mm}$. Utilizing the multi-beam technology, the images obtained from the four channels were averaged. In OCT, the reflectivity profile was termed as an axial scan (A-scan or A-line). By grouping together several A-lines for different transversal positions of the incident beam on the sample, a cross-section image or a B-scan was generated [78]. The images obtained with this OCT system were B-Scan images with a size of $6 \mathrm{~mm} \times 2 \mathrm{~mm}$ and software inferred C-scan images with a size of $6 \mathrm{~mm} \times 6 \mathrm{~mm}$. 


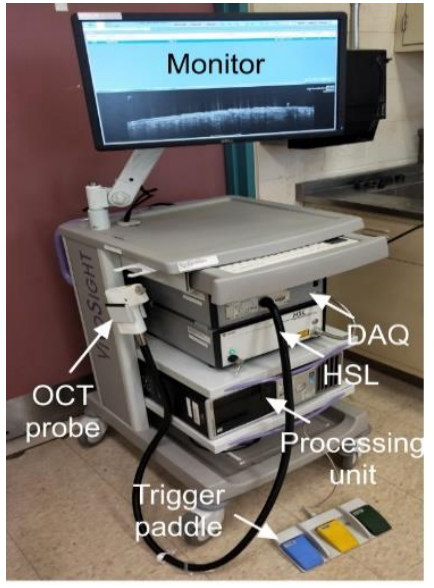

(a)

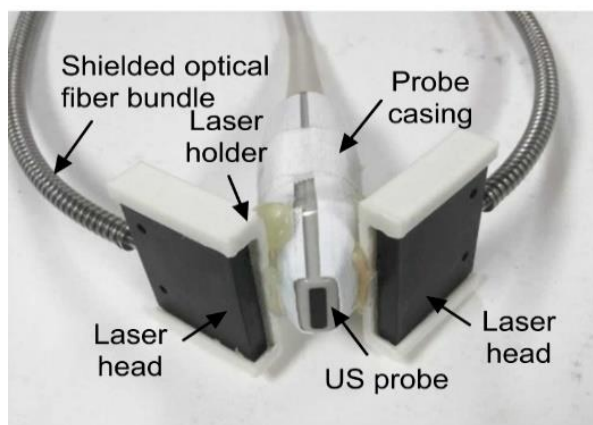

(c)

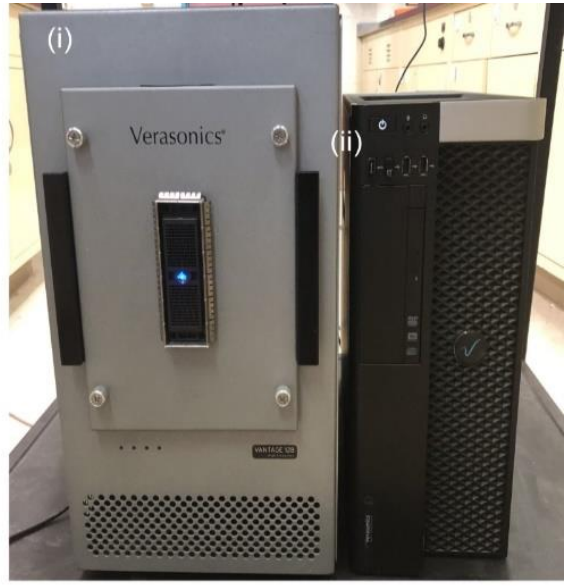

(b)

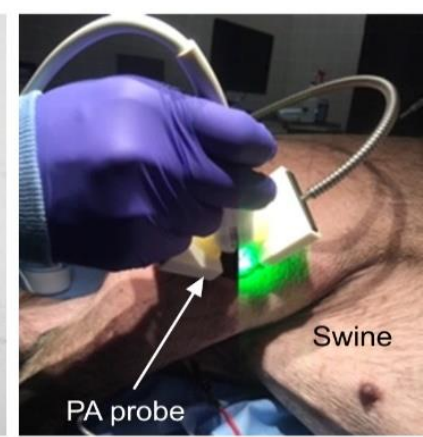

(d)

Figure 2. Ultrasound (US)/photoacoustic (PA) system components. (a) Optical coherence tomography (OCT) system. (b) US/PA DAQ, processing, and storage units, (i) Vantage 128 DAQ system, and (ii) processing unit. (c) US/PA probe specifications. (d) US/PA probe in use on swine melanoma lesion. DAQ: Data acquisition unit, HSL: High-speed swept-source laser.

We conducted studies in a melanoma swine model (Sinclair Bio-Resources, LLC, Columbia, MO, USA) with histologically verified melanoma and adjacent normal skin (Figure 3). The swine melanoma model was used because of the similarities between human and porcine skin $[79,80]$, particularly the epidermal structure and thickness [81-84]; the epidermal/dermal junction is also similar to humans.

For each imaging session, the swine model was sedated with $4.4 \mathrm{mg} / \mathrm{kg}$ of telazol and $2.2 \mathrm{mg} / \mathrm{kg}$ of xylazine, i.m. administered, prior to the experiment. Ketamine/diazepam was administered via the catheter to effect in order to induce general anesthesia and permit endotracheal intubation, and isoflurane was administered using a precision vaporizer and ventilator. A rumen tube was placed orally to permit removal of gastric contents. The eyes were lubricated with a petrolatum-based product. Heart and respiratory rates, indirect blood pressure, pulse oxygenation, and end tidal $\mathrm{CO}_{2}$ were monitored throughout the procedure. Hair on the regions of interest was removed with a shaving clipper and the site was scrubbed three times, alternating between Betadine scrub and alcohol. There were two regions of interest (ROIs): A small lesion on the abdomen and a large lesion on the flank (Figure 3) were imaged with both the US/PA and the OCT system. Healthy skin adjacent to the suspect lesions was also imaged for comparative assessment. US images of all lesions were acquired followed by PA images taken at both $532 \mathrm{~nm}$ and $1064 \mathrm{~nm}$. Biopsies were then taken from each lesion. 

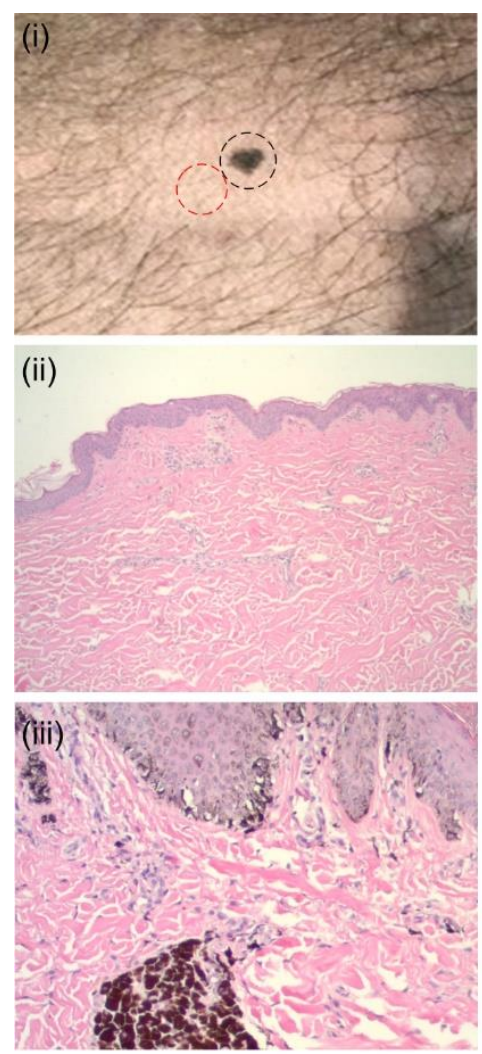

(a)
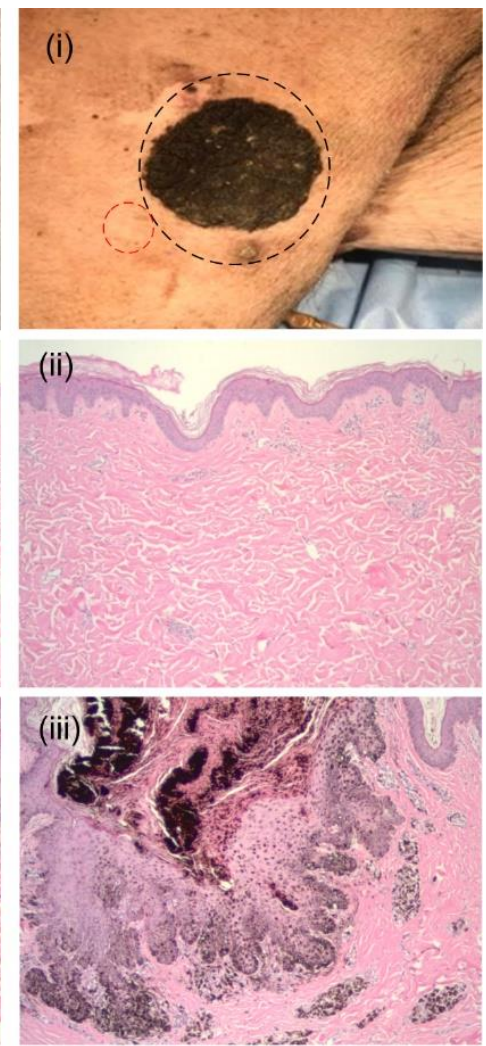

(b)

Figure 3. Imaged suspect lesions. (a) (i) Abdominal, dark-brown pigmented plaque with irregular border confirmed as melanoma (black-circle), (ii) histology of nearby healthy skin (red-circle), and (iii) histology of the suspect lesion. (b) (i) Flank, large dark-brown plaque confirmed as melanoma (circled), (ii) histology of nearby healthy skin, and (iii) histology of the suspect lesion.

\section{Results and Discussion}

Ultrasound images of both melanoma and nearby healthy skin with the annotations of different regions are shown in Figure 4. It was evident that the melanomas had a dimmer epidermis signal compared to the nearby healthy tissue (Figure 4), implying a reduced US echo from this layer that could be caused by a reduced impedance mismatch between the epidermis and dermis. The lowered melanoma epidermal signal was unexpected, as the density of melanoma cells was greater than healthy tissue, which should result in a greater echo from the lesion. We expect that the melanoma epidermis was dimmer due to irregularity of rete ridges, resulting in major scattering of the acoustic waves. The echogenicity of the two tissues was different. The signal was quantified through the average pixel value of the image and demonstrated in Figure 4c with averaged pixels within the yellow dashes of Figure $4 a, b$. Further, the dermis was more visible in the healthy tissue, allowing the visualization of fibrotic septa in the dermis of the healthy tissue images. The decreased melanoma dermis signal was due to the disruption of normal tissue architecture from the invasion of melanocytes, resulting in the loss of a clear boundary between the dermis and subcutaneous layers.

OCT imaging was conducted using a triaxial holder to maintain the OCT probe perpendicular to the sample surface. A total of 170 images in the free-run mode of the OCT were collected. In Figure 5, two slides of each lesion and its nearby healthy region are shown. The melanomas displayed a thickened epidermis with more disordered architecture, as also demonstrated in [17]. Rete ridges in melanoma were larger and broader. There were large melanoma nests in the superficial dermis which, combined with the irregularity of the rete ridges, made visualization of the dermal-epidermal junction (DEJ) $[85,86]$ more difficult. These results are consistent with the findings in the literature [87-95]. 


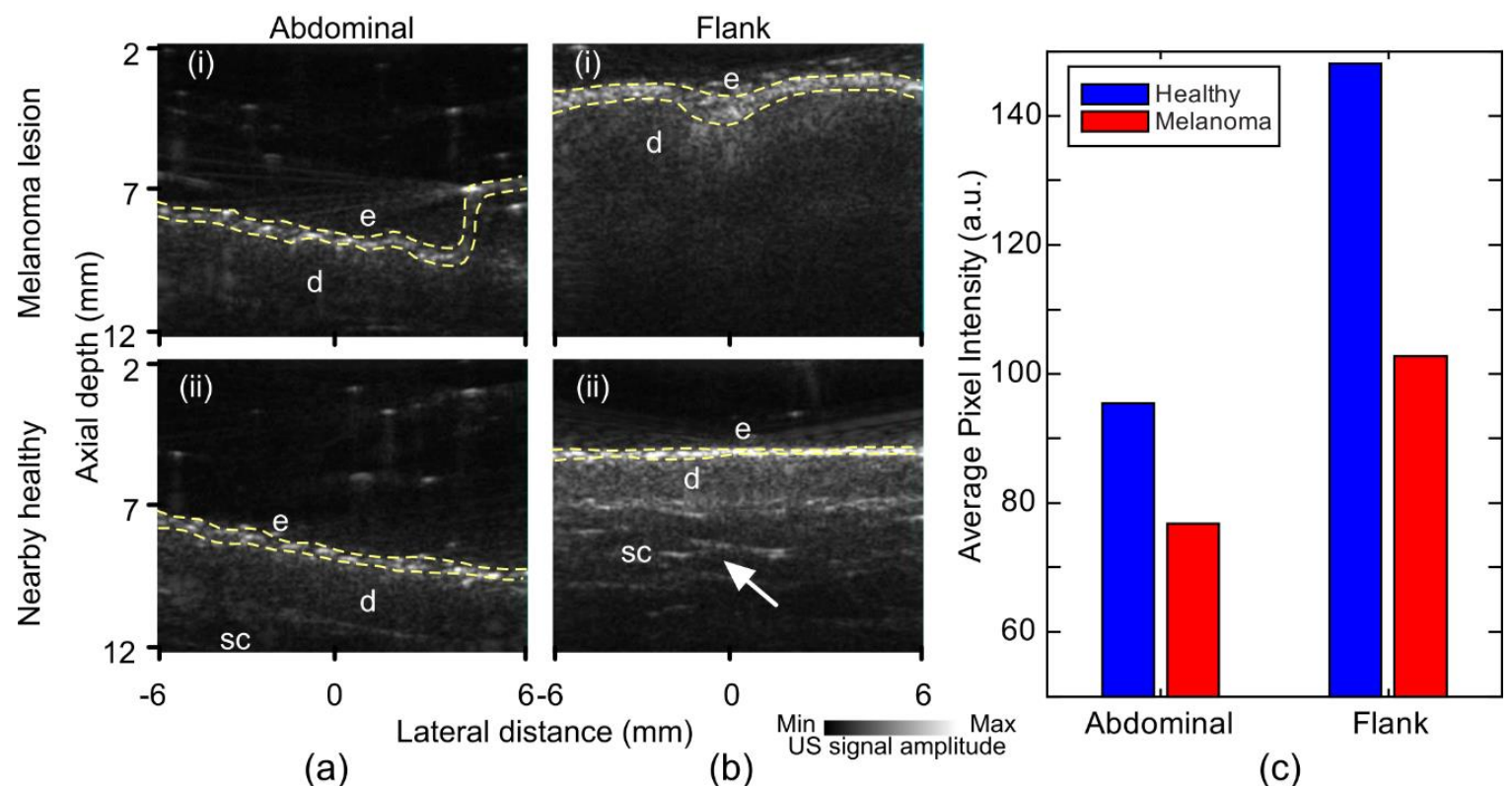

Figure 4. Ultrasound images of melanoma lesion and nearby healthy skin. (a) Abdominal: (i) Lesion, (ii) nearby healthy. (b) Flank: (i) Lesion, (ii) healthy. (c) Bar chart of average pixel intensity from epidermal region of US images. E: Epidermis, d: Dermis, sc: Subcutaneous tissue. Fibrotic septa (arrows), epidermal layer pixels (yellow dashes).
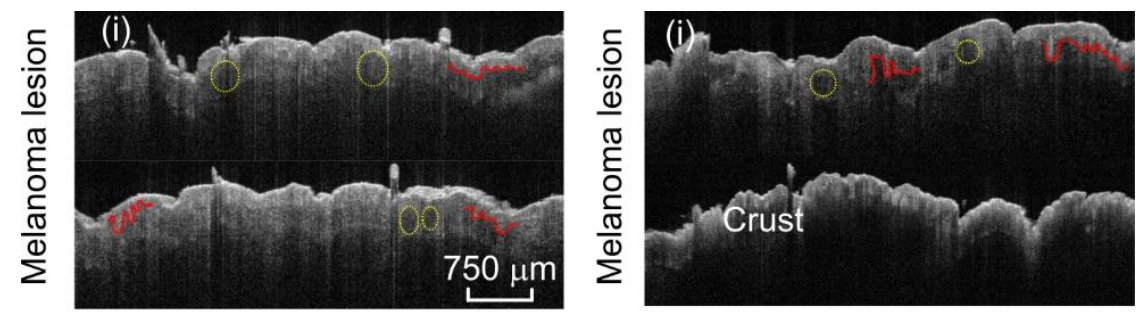

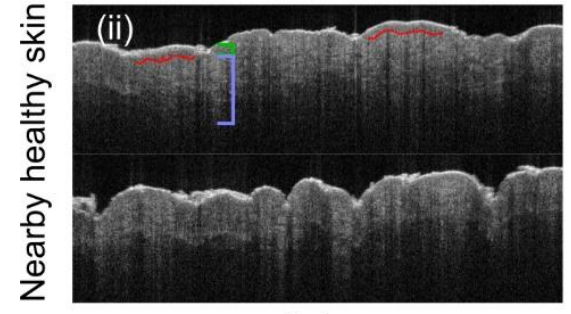

(a)

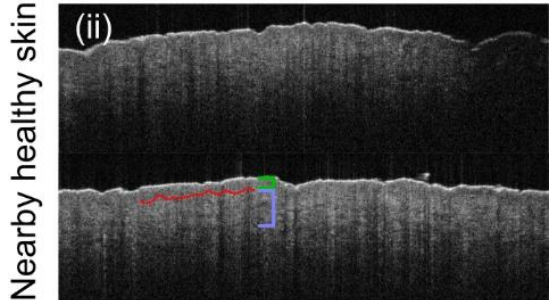

(b)

OCT signal amplitude

Figure 5. OCT images of melanoma lesion and nearby healthy skin. (a) Abdominal: (i) Lesion and (ii) healthy. (b) Flank: (i) Lesion and (ii) healthy. Melanomas demonstrate disorganization and thickening of the epidermis, larger rete ridges, an obscured dermal-epidermal junction (DEJ), and dermal tumor nests. Yellow circles: Dermal nests of melanocytes. Red lines: Dermal-epidermal junction. Green brackets: Epidermis. Light blue brackets: Dermis. 
Photoacoustic images acquired at $532 \mathrm{~nm}$ wavelength are shown in Figure 6. The main difference between the melanoma and the healthy tissue at $532 \mathrm{~nm}$ wavelength was the PA signal strength from the epidermis. Figure $6 \mathrm{c}$ shows the average pixel intensity of the epidermal region at $532 \mathrm{~nm}$ photoacoustic imaging of both lesions and nearby healthy skin. The flank melanoma in Figure $6 \mathrm{~b}(\mathrm{i})$, appeared to produce a stronger photoacoustic signal than the healthy tissue at this wavelength, most likely due to the presence of an increased amount of melanin in the epidermis and, thus, higher absorption. In contrast, in the healthy skin a low and uniform photoacoustic signal can be seen in the epidermis, which corresponded to normal melanin distribution in the epidermis (Figure 6a(ii),b(ii)).

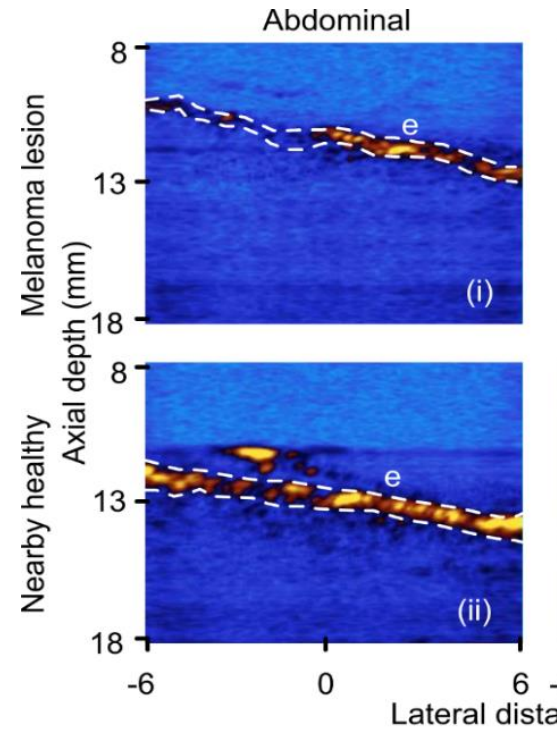

(a)

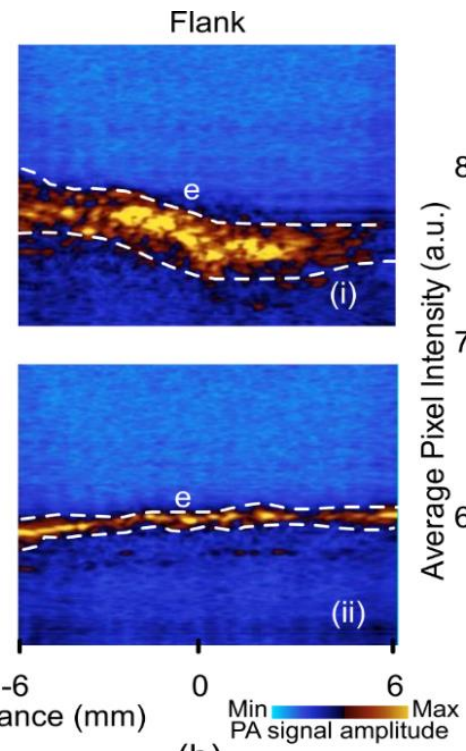

(b)

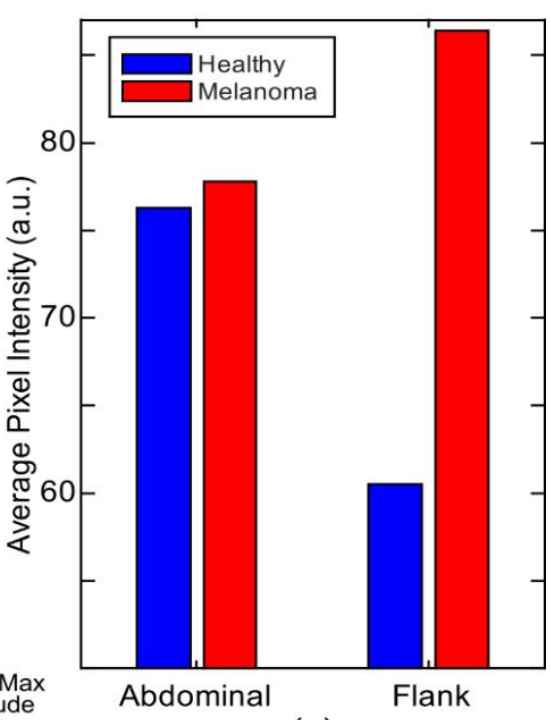

(c)

Figure 6. Photoacoustic images of melanoma lesion and nearby healthy skin at $532 \mathrm{~nm}$ illumination wavelength. (a) Abdominal: (i) Lesion and (ii) healthy. (b) Flank: (i) Lesion and (ii) healthy. (c) Bar chart of average pixel intensity from epidermal region in the PA images of $532 \mathrm{~nm}$. E: Epidermis. Epidermal pixels (white dashes). The PA signal was increased in the melanoma, highlighting the increase in melanin.

Photoacoustic images acquired at $1064 \mathrm{~nm}$ wavelength with annotations are shown in Figure 7. At this wavelength, it appeared that the photoacoustic signal from the epidermis had a higher intensity from melanoma as compared to the normal skin (Figure $7 a(i), b(i)$ ). Image quantification extracted from the average epidermal signal strength is shown in Figure 7c, with averaged pixels within the white dashes of Figure 7a,b. This signal continued into the superficial dermis in melanoma. Furthermore, with the deeper penetration of light from the longer wavelength, fibrotic septa can also be seen in healthy tissue (Figure 7a(ii)) similar to those seen in the ultrasound images. The difference in the signal strength between the healthy regions was due to the change in gain settings to avoid any image saturation from the flank region. 


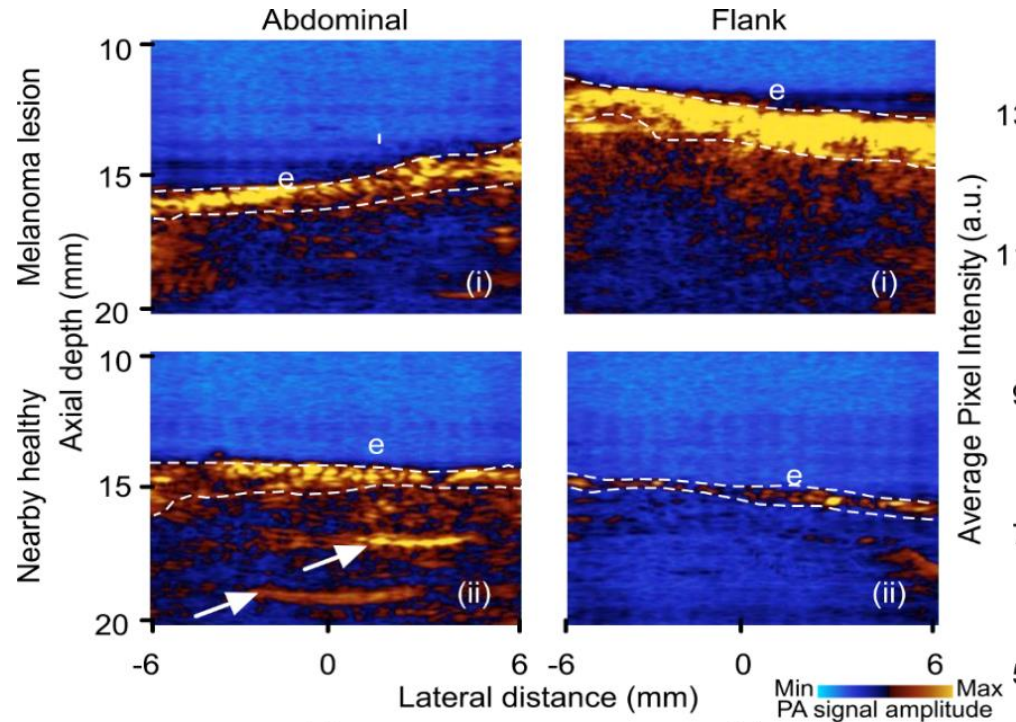

(a)

(b)

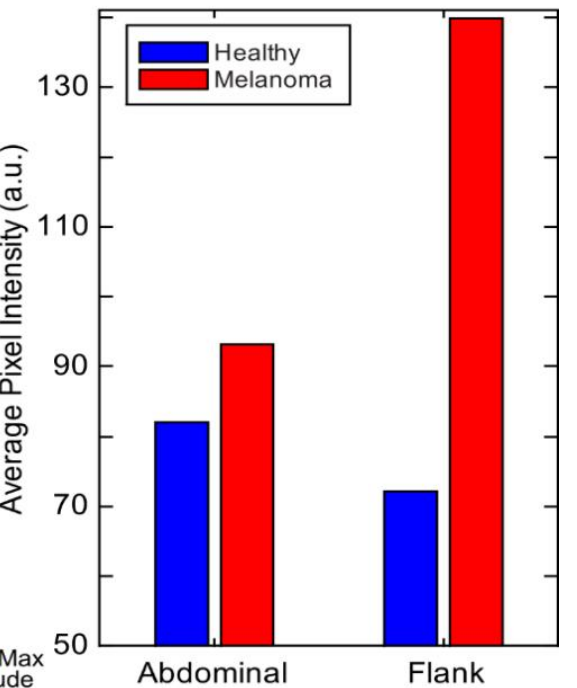

(c)

Figure 7. Photoacoustic images of melanoma lesion and nearby healthy skin at $1064 \mathrm{~nm}$ illumination wavelength. (a) Abdominal: (i) Lesion and (ii) healthy. (b) Flank: (i) Lesion and (ii) healthy. (c) Bar chart of average pixel intensity from epidermal region at $1064 \mathrm{~nm}$ images. E: Epidermis. Fibrotic septa (arrows); averaged epidermal pixels (white dashes).

In Table 2, we have summarized the capability, advantages, and limitations of each of the imaging modalities used for this study.

Table 2. Advantages and disadvantages of US, OCT, and PA imaging for melanoma imaging.

\begin{tabular}{cllll}
\hline $\begin{array}{c}\text { Imaging } \\
\text { Modality }\end{array}$ & \multicolumn{1}{c}{ Imaging Capability } & \multicolumn{1}{c}{ Advantage } & \multicolumn{1}{c}{ Limitations } & Findings in Lesional Area \\
\hline US & $\begin{array}{l}\text { Structural-morphology of } \\
\text { different structures in skin }\end{array}$ & $\begin{array}{l}\text { Penetration depth } \\
\text { (up to } 2 \mathrm{~cm})\end{array}$ & $\begin{array}{l}\text { Insufficient resolution } \\
\text { even using } \\
\text { high-frequency probes }\end{array}$ & $\begin{array}{l}\text { (i) Weaker signal from } \\
\text { epidermis and dermis } \\
\text { (ii) Absence of fibrotic } \\
\text { septa }\end{array}$ \\
\hline \multirow{2}{*}{ OCT } & $\begin{array}{l}\text { High-resolution } \\
\text { morphology }\end{array}$ & $\begin{array}{l}\text { Superior resolution } \\
(1 \sim 10 \mu \text { m depending on } \\
\text { the configuration of } \\
\text { OCT) }\end{array}$ & $\begin{array}{l}\text { Limited penetration } \\
\text { depth }(\sim 1.5 \mathrm{~mm})\end{array}$ & $\begin{array}{l}\text { (i) Broadened shape of rete } \\
\text { ridges } \\
\text { (ii) Less defined } \\
\text { dermal-epidermal } \\
\text { junction }\end{array}$ \\
\hline \multirow{2}{*}{ PA } & $\begin{array}{l}\text { Vascular pattern and } \\
\text { oxygenation maps }\end{array}$ & Multispectral imaging & $\begin{array}{l}\text { Insufficient resolution } \\
\text { for cellular imaging }\end{array}$ & $\begin{array}{l}\text { (i) Stronger signal from } \\
\text { epidermis layer }\end{array}$ \\
\hline
\end{tabular}

Although the US images showed structural differences between the melanoma and healthy skin, this modality was unable to identify micron-level morphological changes in the skin due to melanoma. Therefore, US can provide information on the size and shape of a lesion, but cannot provide details regarding the diagnosis or malignant potential. Higher frequency US probes could enable cellular imaging while maintaining a sufficient penetration depth and provide more specificity for diagnosis. OCT helped to display disordered architectural organization in rete ridges and the dermal-epidermal junction, and helped visualize the infiltrative nature of the tumor [96]. With photoacoustic imaging (PA), we were able to extract information related to melanin content in the tumors through epidermal signal strength. As shown in Figure 1b, $532 \mathrm{~nm}$ illumination will have the greatest PA signal from high absorption of oxy- and deoxy-hemoglobin with some signal from lower absorption of melanin and minimal absorption of water. This wavelength may allow for the staging of angiogenesis in the melanoma lesion. In Figure 1b, 1064 nm illumination had comparable absorption by oxy-, deoxy-hemoglobin, and melanin, and minimal absorption from water. This wavelength may show 
changes in the melanin content in the lesion. Exact contributions to photoacoustic signals from multiple optical absorbers require the use of photoacoustic spectroscopy, i.e., semi-simultaneous imaging using several wavelengths [96]. As we did not have access to a broad-spectrum tunable laser source for this study, only total absorption was explored in our images. Moreover, the oxygen uptake rate of cancerous tissue was higher as compared to normal skin, which can be measured in the PA images. PA was also capable of detecting the bottom boundary of the tumor. Limitations observed in each of these imaging modalities led us to believe that a combined US/PA/OCT imaging technique could help clinicians in the diagnosis of melanoma.

\section{Conclusions}

There is a need for a non-invasive in vivo imaging for rapid diagnosis of melanoma. We presented the results of three imaging modalities-ultrasound, optical coherence tomography, and photoacoustic imaging - to study the image features of melanoma compared to those in nearby healthy skin tissue and evaluated their clinical capability. It can be seen that there are subtle differences between lesioned and healthy tissues in the US: A stronger signal from the epidermis and dermis, and a presence of fibrotic septa in healthy tissue, whereas comparatively weaker US intensity and no presence of fibrotic septa was observed at the melanoma site. We were able to visualize the micron-level morphological differences between the melanoma and healthy tissues for thin lesions using OCT. Melanoma lesions displayed a more disordered architectural organization in OCT images, rete ridges with a broadened shape, and a less defined dermal-epidermal junction due to the infiltrative nature of the tumor growth and the irregularity of rete ridges. In PA imaging, the use of $532 \mathrm{~nm}$ wavelength illumination demonstrated a difference in the epidermal signal, with melanoma lesions being stronger most likely due to greater pigmentation. The $1064 \mathrm{~nm}$ illumination presented a stronger epidermal signal; however, it also provided the information regarding the presence of fibrotic septa in the healthy tissue due to deeper illumination penetration. Our findings are not necessarily specific to melanoma since we did not have access to benign nevi lesion in the same animal for a fair comparison. Further, the melanomas imaged were thick with large nests of melanocytes. These observations may not pertain to imaging early, thin melanoma. More research is necessary to determine which findings are specific to melanoma and whether or not they can be used to distinguish melanoma and benign melanocytic tumors.

Combining our observations, healthy skin demonstrated fibrotic septa in the subcutaneous region in US, thinner epidermis with patterned structure in OCT, and a lower average PA signal intensity from epidermis. In melanoma, we observed a reduced dermal signal in US, a stronger epidermal photoacoustic signal intensity, and larger and broader rete ridges in OCT.

This pilot study evaluated differences between melanoma and healthy tissue and we are looking to perform evaluations on a larger number of samples to confirm the trends seen in the images provided in this study.

Author Contributions: Conceptualization, M.A.; methodology, M.A.; software, K.K. and R.M.; validation, R.M., A.R., J.M., S.D., and M.A.; formal analysis, K.K., R.M., A.R., J.F., S.D., and M.A.; investigation, K.K., R.M., A.R., J.F., S.D., and M.A.; data curation, K.K. and R.M.; writing-original draft preparation, K.K., R.M., and J.F.; writing-review and editing, K.K., R.M., A.R., J.M., S.D., D.M., and M.A.; visualization, K.K. and R.M.; supervision, M.A.

Funding: MI-Kickstart Early-Stage Funding-Fast Forward Medical Innovation.

Acknowledgments: The authors would like to thank Gerry Hish, DLAR, Wayne State University, Michelson Diagnosis, and Verasonics Inc.

Conflicts of Interest: The authors declare no conflict of interest. 


\section{References}

1. National Cancer Institute Surveillance, Epidemiology, and End Results Program. Cancer Stat Facts: Melanoma of the Skin. In Cancer Stat Facts; National Institutes of Health: Washington, DC, USA, 2016.

2. Siegel, R.L.; Miller, K.D.; Jemal, A. Cancer statistics, 2016. CA Cancer J. Clin. 2016, 66, 7-30. [CrossRef] [PubMed]

3. Jemal, A.; Devesa, S.S.; Hartge, P.; Tucker, M.A. Recent trends in cutaneous melanoma incidence among whites in the United States. J. Natl. Cancer Inst. 2001, 93, 678-683. [CrossRef] [PubMed]

4. American Cancer Society. Cancer Facts E Figures 2018; American Cancer Society: Atlanta, GA, USA, 2018.

5. Hieken, T.J.; Hernández-Irizarry, R.; Boll, J.M.; Jones Coleman, J.E. Accuracy of diagnostic biopsy for cutaneous melanoma: Implications for surgical oncologists. Int. J. Surg. Oncol. 2013, 2013, 196493. [CrossRef] [PubMed]

6. Marshall, C.D.; Hu, M.S.; Leavitt, T.; Barnes, L.A.; Lorenz, H.P.; Longaker, M.T. Cutaneous scarring: Basic science, current treatments, and future directions. Adv. Wound Care 2018, 7, 29-45. [CrossRef] [PubMed]

7. Ramsey, M.L.; Rostami, S. Skin Biopsy. In StatPearls [Internet]; StatPearls Publishing: Tampa, FL, USA, 2019.

8. Ng, J.C.; Swain, S.; Dowling, J.P.; Wolfe, R.; Simpson, P.; Kelly, J.W. The Impact of Partial Biopsy on Histopathologic Diagnosis of Cutaneous Melanoma: Experience of an Australian Tertiary Referral Service. Arch. Dermatol. 2010, 146, 234-239. [CrossRef] [PubMed]

9. Dummer, W.; Blaheta, H.-J.; Bastian, B.C.; Schenk, T.; Bröcker, E.-B.; Remy, W. Preoperative characterization of pigmented skin lesions by epiluminescence microscopy and high-frequency ultrasound. Arch. Dermatol. 1995, 131, 279-285. [CrossRef] [PubMed]

10. Bard, R.L. High-Frequency Ultrasound Examination in the Diagnosis of Skin Cancer. Derm. Clin. 2017, 35, 505-511. [CrossRef] [PubMed]

11. Dinnes, J.; Bamber, J.; Chuchu, N.; Bayliss, S.E.; Takwoingi, Y.; Davenport, C.; Godfrey, K.; O'Sullivan, C.; Matin, R.N.; Deeks, J.J.; et al. High-frequency ultrasound for diagnosing skin cancer in adults. Cochrane Database Syst. Rev. 2018, 12, CD013188. [CrossRef]

12. Botar-Jid, C.M.; Cosgarea, R.; Bolboacă, S.D.; Şenilă, S.C.; Lenghel, L.M.; Rogojan, L.; Dudea, S.M. Assessment of Cutaneous Melanoma by Use of Very-High-Frequency Ultrasound and Real-Time Elastography. Am. J. Roentgenol. 2016, 206, 699-704. [CrossRef]

13. Segura, S.; Puig, S.; Carrera, C.; Palou, J.; Malvehy, J. Development of a two-step method for the diagnosis of melanoma by reflectance confocal microscopy. J. Am. Acad. Dermatol. 2009, 61, 216-229. [CrossRef]

14. Gambichler, T.; Regeniter, P.; Bechara, F.G.; Orlikov, A.; Vasa, R.; Moussa, G.; Stücker, M.; Altmeyer, P.; Hoffmann, K. Characterization of benign and malignant melanocytic skin lesions using optical coherence tomography in vivo. J. Am. Acad. Dermatol. 2007, 57, 629-637. [CrossRef] [PubMed]

15. Xiong, Y.Q.; Mo, Y.; Wen, Y.Q.; Cheng, M.J.; Huo, S.T.; Chen, X.J.; Chen, Q. Optical coherence tomography for the diagnosis of malignant skin tumors: A meta-analysis. J. Biomed. Opt. 2018, 23, 20902. [CrossRef] [PubMed]

16. Ferrante di Ruffano, L.; Dinnes, J.; Deeks, J.J.; Chuchu, N.; Bayliss, S.E.; Davenport, C.; Takwoingi, Y.; Godfrey, K.; O'Sullivan, C.; Matin, R.N.; et al. Optical coherence tomography for diagnosing skin cancer in adults. Cochrane Database Syst. Rev. 2018, 12, CD013189. [CrossRef] [PubMed]

17. Rajabi-Estarabadi, A.; Bittar, J.M.; Zheng, C.; Nascimento, V.; Camacho, I.; Feun, L.G.; Nasiriavanaki, M.; Kunz, M.; Nouri, K. Optical coherence tomography imaging of melanoma skin cancer. Lasers Med. Sci. 2019, 34, 411-420. [CrossRef] [PubMed]

18. Hojjatoleslami, A.; Avanaki, M. OCT skin image enhancement through attenuation compensation. Appl. Opt. 2012, 51, 4927-4935. [CrossRef] [PubMed]

19. Hojjatoleslami, S.; Avanaki, M.; Podoleanu, A.G. Image quality improvement in optical coherence tomography using Lucy-Richardson deconvolution algorithm. Appl. Opt. 2013, 52, 5663-5670. [CrossRef] [PubMed]

20. Avanaki, M.R.; Hojjatoleslami, A.; Sira, M.; Schofield, J.B.; Jones, C.; Podoleanu, A.G. Investigation of basal cell carcinoma using dynamic focus optical coherence tomography. Appl. Opt. 2013, 52, 2116-2124. [CrossRef]

21. Avanaki, M.R.; Hojjat, A.; Podoleanu, A.G. Investigation of computer-based skin cancer detection using optical coherence tomography. J. Mod. Opt. 2009, 56, 1536-1544. [CrossRef] 
22. Avanaki, M.R.; Hojjatoleslami, A. Skin layer detection of optical coherence tomography images. Opt. Int. J. Light Electron. Opt. 2013, 124, 5665-5668. [CrossRef]

23. Xu, Q.; Adabi, S.; Clayton, A.; Daveluy, S.; Mehregan, D.; Nasiriavanaki, M. Swept-Source Optical Coherence Tomography-Supervised Biopsy. Dermatol. Surg. 2018, 44, 768-775. [CrossRef]

24. Rey-Barroso, L.; Burgos-Fernández, F.; Delpueyo, X.; Ares, M.; Royo, S.; Malvehy, J.; Puig, S.; Vilaseca, M. Visible and extended near-infrared multispectral imaging for skin cancer diagnosis. Sensors 2018, 18, 1441. [CrossRef] [PubMed]

25. Tomatis, S.; Bono, A.; Bartoli, C.; Carrara, M.; Lualdi, M.; Tragni, G.; Marchesini, R. Automated melanoma detection: Multispectral imaging and neural network approach for classification. Med. Phys. 2003, 30, 212-221. [CrossRef] [PubMed]

26. Diebele, I.; Bekina, A.; Derjabo, A.; Kapostinsh, J.; Kuzmina, I.; Spigulis, J. Analysis of skin basalioma and melanoma by multispectral imaging. In Biophotonics: Photonic Solutions for Better Health Care III; International Society for Optics and Photonics: Bellingham, WA, USA, 2012.

27. Martin, J.; Krueger, J.; Gareau, D. Hyperspectral imaging for melanoma screening. In Photonic Therapeutics and Diagnostics X; International Society for Optics and Photonics: Bellingham, WA, USA, 2014.

28. Pardo, A.; Gutiérrez-Gutiérrez, J.A.; Lihacova, I.; López-Higuera, J.M.; Conde, O.M. On the spectral signature of melanoma: A non-parametric classification framework for cancer detection in hyperspectral imaging of melanocytic lesions. Biomed. Opt. Express 2018, 9, 6283-6301. [CrossRef] [PubMed]

29. Hosking, A.M.; Coakley, B.J.; Chang, D.; Talebi-Liasi, F.; Lish, S.; Lee, S.W.; Zong, A.M.; Moore, I.; Browning, J.; Jacques, S.L. Hyperspectral imaging in automated digital dermoscopy screening for melanoma. Lasers Surg. Med. 2019. [CrossRef] [PubMed]

30. Yorucu, C.; Lau, K.; Mittar, S.; Green, N.H.; Raza, A.; Rehman, I.U.; MacNeil, S. Raman spectroscopy detects melanoma and the tissue surrounding melanoma using tissue-engineered melanoma models. Appl. Spectrosc. Rev. 2016, 51, 263-277. [CrossRef] [PubMed]

31. Gniadecka, M.; Philipsen, P.A.; Wessel, S.; Gniadecki, R.; Wulf, H.C.; Sigurdsson, S.; Nielsen, O.F.; Christensen, D.H.; Hercogova, J.; Rossen, K. Melanoma diagnosis by Raman spectroscopy and neural networks: Structure alterations in proteins and lipids in intact cancer tissue. J. Investig. Dermatol. 2004, 122, 443-449. [CrossRef]

32. Feng, X.; Moy, A.J.; Nguyen, H.T.; Zhang, J.; Fox, M.C.; Sebastian, K.R.; Reichenberg, J.S.; Markey, M.K.; Tunnell, J.W. Raman active components of skin cancer. Biomed. Opt. Express 2017, 8, 2835-2850. [CrossRef]

33. Åberg, P.; Birgersson, U.; Elsner, P.; Mohr, P.; Ollmar, S. Electrical impedance spectroscopy and the diagnostic accuracy for malignant melanoma. Exp. Dermatol. 2011, 20, 648-652. [CrossRef]

34. Rocha, L.; Menzies, S.W.; Lo, S.; Avramidis, M.; Khoury, R.; Jackett, L.; Guitera, P. Analysis of an electrical impedance spectroscopy system in short-term digital dermoscopy imaging of melanocytic lesions. Br. J. Dermatol. 2017, 177, 1432-1438. [CrossRef]

35. Mohr, P.; Birgersson, U.; Berking, C.; Henderson, C.; Trefzer, U.; Kemeny, L.; Sunderkötter, C.; Dirschka, T.; Motley, R.; Frohm-Nilsson, M.; et al. Electrical impedance spectroscopy as a potential adjunct diagnostic tool for cutaneous melanoma. Ski. Res. Technol. 2013, 19, 75-83. [CrossRef]

36. Panchal, R.; Horton, L.; Poozesh, P.; Baqersad, J.; Nasiriavanaki, M. Vibration Analysis of Healthy Skin: Toward a Noninvasive Skin Diagnosis Methodology; SPIE: Bellingham, WA, USA, 2019; Volume 24, p. 11.

37. Emiroglu, N.; Pelin Cengiz, F.; Hofmann-Wellenhof, R. Dermoscopic and clinical features of trunk melanomas. Postepy Derm. Alergol. 2014, 31, 362-367. [CrossRef] [PubMed]

38. Herschorn, A. Dermoscopy for melanoma detection in family practice. Can. Fam. Physician 2012, 58, 740-745. [PubMed]

39. Stanganelli, I.; Pizzichetta, M. Dermoscopy. In Clinical Procedures, Drugs and Diseases, 13th ed.; MedScape: Lake Tahoe, CA, USA, 2018.

40. Dinnes, J.; Deeks, J.J.; Saleh, D.; Chuchu, N.; Bayliss, S.E.; Patel, L.; Davenport, C.; Takwoingi, Y.; Godfrey, K.; Matin, R.N.; et al. Reflectance confocal microscopy for diagnosing cutaneous melanoma in adults. Cochrane Database Syst. Rev. 2018. [CrossRef] [PubMed]

41. Waddell, A.; Star, P.; Guitera, P. Advances in the use of reflectance confocal microscopy in melanoma. Melanoma Manag. 2018, 5, MMT04. [CrossRef] [PubMed]

42. Markowitz, O.; Levine, A. In Vivo Reflectance Confocal Microscopy; Cutis: Parsippany, NJ, USA, 2017; pp. 399-402. 
43. Xia, J.; Li, G.; Wang, L.; Nasiriavanaki, M.; Maslov, K.; Engelbach, J.A.; Garbow, J.R.; Wang, L.V. Wide-field two-dimensional multifocal optical-resolution photoacoustic-computed microscopy. Opt. Lett. 2013, 38, 5236-5239. [CrossRef]

44. Hariri, A.; Fatima, A.; Mohammadian, N.; Bely, N.; Nasiriavanaki, M. Towards low cost photoacoustic microscopy system for evaluation of skin health. In Imaging Spectrometry XXI; International Society for Optics and Photonics: Bellingham, WA, USA, 2016.

45. Adabi, S.; Hosseinzadeh, M.; Noei, S.; Conforto, S.; Daveluy, S.; Clayton, A.; Mehregan, D.; Nasiriavanaki, M. Universal in vivo textural model for human skin based on optical coherence tomograms. Sci. Rep. 2017, 7, 17912. [CrossRef] [PubMed]

46. Nie, L.; Guo, Z.; Wang, L.V. Photoacoustic tomography of monkey brain using virtual point ultrasonic transducers. J. Biomed. Opt. 2011, 16, 076005. [CrossRef]

47. Manwar, R.; Hosseinzadeh, M.; Hariri, A.; Kratkiewicz, K.; Noei, S.; NAvanaki, M. Avanaki Photoacoustic Signal Enhancement: Towards Utilization of Low Energy Laser Diodes in Real-Time Photoacoustic Imaging. Sensors 2018, 18, 3498. [CrossRef]

48. Yao, J.; Wang, L.V. Photoacoustic brain imaging: From microscopic to macroscopic scales. Neurophotonics 2014, 1, 11003. [CrossRef]

49. Fayyaz, Z.; Mohammadian, N.; Tabar, M.; Manwar, R.; Avanaki, M. A Comparative Study of Optimization Algorithms for Wavefront Shaping. J. Innov. Opt. Health Sci. 2019. [CrossRef]

50. Hariri, A.; Fatima, A.; Mohammadian, N.; Mahmoodkalayeh, S.; Ansari, M.A.; Bely, N.; Avanaki, M.R. Development of low-cost photoacoustic imaging systems using very low-energy pulsed laser diodes. J. Biomed. Opt. 2017, 22, 075001. [CrossRef] [PubMed]

51. Kratkiewicz, K.; Manwar, R.; Zafar, M.; Zhang, R.; Huang, B.; Dadashzadesh, N.; Xia, J.; Avanaki, M. Review of Cost Reduction Methods in Photoacoustic Computed Tomography. arXiv, 2019; arXiv:1902.09987.

52. Mohammadi-Nejad, A.-R.; Mahmoudzadeh, M.; Hassanpour, M.S.; Wallois, F.; Muzik, O.; Papadelis, C.; Hansen, A.; Soltanian-Zadeh, H.; Gelovani, J.; Nasiriavanaki, M. Neonatal brain resting-state functional connectivity imaging modalities. Photoacoustics 2018, 10, 1-19. [CrossRef] [PubMed]

53. Nasiriavanaki, M.; Xia, J.; Wan, H.; Bauer, A.Q.; Culver, J.P.; Wang, L.V. High-resolution photoacoustic tomography of resting-state functional connectivity in the mouse brain. Proc. Natl. Acad. Sci. USA 2014, 111, 21-26. [CrossRef]

54. Wang, L.V. Tutorial on photoacoustic microscopy and computed tomography. IEEE J. Sel. Top. Quantum Electron. 2008, 14, 171-179. [CrossRef]

55. Zafar, M.; Kratkiewicz, K.; Manwar, R.; Avanaki, M. Development of Low-Cost Fast Photoacoustic Computed Tomography: System Characterization and Phantom Study. Appl. Sci. 2019, 9, 374. [CrossRef]

56. Zhou, Y.; Yao, J.; Wang, L.V. Tutorial on photoacoustic tomography. J. Biomed. Opt. 2016, $21,061007$. [CrossRef]

57. Mozaffarzadeh, M.; Mahloojifar, A.; Orooji, M.; Adabi, S.; Nasiriavanaki, M. Double-Stage Delay Multiply and Sum Beamforming Algorithm: Application to Linear-Array Photoacoustic Imaging. IEEE Trans. Biomed. Eng. 2018, 65, 31-42. [CrossRef]

58. Mahmoodkalayeh, S.; Jooya, H.Z.; Hariri, A.; Zhou, Y.; Xu, Q.; Ansari, M.A.; Avanaki, M.R. Low temperature-mediated enhancement of photoacoustic imaging depth. Sci. Rep. 2018, 8, 4873. [CrossRef]

59. Mozaffarzadeh, M.; Mahloojifar, A.; Orooji, M.; Kratkiewicz, K.; Adabi, S.; Nasiriavanaki, M. Linear-array photoacoustic imaging using minimum variance-based delay multiply and sum adaptive beamforming algorithm. J. Biomed. Opt. 2018, 23, 026002. [CrossRef]

60. Omidi, P.; Zafar, M.; Mozaffarzadeh, M.; Hariri, A.; Haung, X.; Orooji, M.; Nasiriavanaki, M. A novel dictionary-based image reconstruction for photoacoustic computed tomography. Appl. Sci. 2018, 8, 1570. [CrossRef]

61. Yao, L.; Jiang, H. Finite-element-based photoacoustic tomography in time domain. J. Opt. A Pure Appl. Opt. 2009, 11, 085301. [CrossRef]

62. Meimani, N.; Abani, N.; Gelovani, J.; Avanaki, M.R. A numerical analysis of a semi-dry coupling configuration in photoacoustic computed tomography for infant brain imaging. Photoacoustics 2017, 7, 27-35. [CrossRef] [PubMed] 
63. Mohammadi, L.; Behnam, H.; Tavakkoli, J.; Nasiriavanaki, M. Skull's acoustic attenuation and dispersion modeling on photoacoustic signal. In Photons Plus Ultrasound: Imaging and Sensing 2018; International Society for Optics and Photonics: Bellingham, WA, USA, 2018.

64. Nasiriavanaki, M. Resting-state functional connectivity measurement in the mouse brain using a low cost photoacoustic computed tomography. In Frontiers in Optics; Optical Society of America: San Diego, CA, USA, 2016.

65. Panchal, R.; Horton, L.; Poozesh, P.; Baqersad, J.; Nasiriavanaki, M. Vibration analysis of healthy skin: Toward a noninvasive skin diagnosis methodology. J. Biomed. Opt. 2019, 24, 015001. [CrossRef]

66. Ranjbaran, S.M.; Kratkiewicz, K.; Manwar, R.; Fallah, H.; Hajimahmoodzadeh, M.; Avanaki, M.R.N. Numerical study on tumor volume detection in the human brain using photoacoustic tomography. In Photons Plus Ultrasound: Imaging and Sensing 2019; International Society for Optics and Photonics: Bellingham, WA, USA, 2019.

67. Yao, J.; Xia, J.; Maslov, K.I.; Nasiriavanaki, M.; Tsytsarev, V.; Demchenko, A.V.; Wang, L.V. Noninvasive photoacoustic computed tomography of mouse brain metabolism in vivo. NeuroImage 2013, 64, $257-266$. [CrossRef] [PubMed]

68. Siphanto, R.; Thumma, K.; Kolkman, R.; Van Leeuwen, T.; De Mul, F.; Van Neck, J.; Van Adrichem, L.; Steenbergen, W. Serial noninvasive photoacoustic imaging of neovascularization in tumor angiogenesis. Opt. Express 2005, 13, 89-95. [CrossRef]

69. Zhou, Y.; Li, G.; Zhu, L.; Li, C.; Cornelius, L.A.; Wang, L.V. Handheld photoacoustic probe to detect both melanoma depth and volume at high speed in vivo. J. Biophotonics 2015, 8, 961-967. [CrossRef]

70. Breathnach, A.; Concannon, E.; Dorairaj, J.J.; Shaharan, S.; McGrath, J.; Jose, J.; Kelly, J.L.; Leahy, M.J. Preoperative measurement of cutaneous melanoma and nevi thickness with photoacoustic imaging. J. Med. Imaging 2018, 5, 015004. [CrossRef]

71. Neuschmelting, V.; Lockau, H.; Ntziachristos, V.; Grimm, J.; Kircher, M.F. Lymph Node Micrometastases and In-Transit Metastases from Melanoma: In Vivo Detection with Multispectral Optoacoustic Imaging in a Mouse Model. Radiology 2016, 280, 137-150. [CrossRef]

72. Stoffels, I.; Morscher, S.; Helfrich, I.; Hillen, U.; Leyh, J.; Burton, N.C.; Sardella, T.C.P.; Claussen, J.; Poeppel, T.D.; Bachmann, H.S.; et al. Metastatic status of sentinel lymph nodes in melanoma determined noninvasively with multispectral optoacoustic imaging. Sci. Transl. Med. 2015, 7, ra199-ra317. [CrossRef]

73. Zhou, Y.; Xing, W.; Maslov, K.I.; Cornelius, L.A.; Wang, L.V. Handheld photoacoustic microscopy to detect melanoma depth in vivo. Opt. Lett. 2014, 39, 4731-4734. [CrossRef] [PubMed]

74. Zhou, W.; Chen, Z.; Yang, S.; Xing, D. Optical biopsy approach to basal cell carcinoma and melanoma based on all-optically integrated photoacoustic and optical coherence tomography. Opt. Lett. 2017, 42, 2145-2148. [CrossRef] [PubMed]

75. Institute, A.N.S. American National Standard for Safe Use of Lasers; Laser Institute of America: Orlando, FL, USA, 2007.

76. Welzel, J.; Lankenau, E.; Hüttmann, G.; Birngruber, R. OCT in Dermatology. In Optical Coherence Tomography; Springer: Berlin/Heidelberg, Germany, 2015; pp. 2189-2207.

77. Avanaki, M.R.N.; Podoleanu, A. En-face time-domain optical coherence tomography with dynamic focus for high-resolution imaging. J. Biomed. Opt. 2017, 22, 056009. [CrossRef] [PubMed]

78. Schmitt, A.M. Principles and application of optical coherent tomography in dermatology. Dermatology 2008, 217, 12-13. [CrossRef] [PubMed]

79. Hook, R., Jr.; Berkelhammer, J.; Oxenhandler, R. Melanoma: Sinclair swine melanoma. Am. J. Pathol. 1982, 108, 130.

80. Gupta, T.D.; Ronan, S.; Beattie, C.; Shilkaitis, A.; Amoss, M., Jr. Comparative histopathology of porcine and human cutaneous melanoma. Pediatr. Dermatol. 1989, 6, 289-299. [CrossRef] [PubMed]

81. Bronaugh, R.L.; Stewart, R.F.; Congdon, E.R. Methods for in vitro percutaneous absorption studies II. Animal models for human skin. Toxicol. Appl. Pharmacol. 1982, 62, 481-488. [CrossRef]

82. Godin, B.; Touitou, E. Transdermal skin delivery: Predictions for humans from in vivo, ex vivo and animal models. Adv. Drug Deliv. Rev. 2007, 59, 1152-1161. [CrossRef]

83. Herron, A. Pigs as dermatologic models of human skin disease. In Proceedings of the ACVP/ASVCP Concurrent Annual Meetings December, Momterey, CA, USA, 5-9 December 2009. 
84. Schmook, F.P.; Meingassner, J.G.; Billich, A. Comparison of human skin or epidermis models with human and animal skin in in-vitro percutaneous absorption. Int. J. Pharm. 2001, 215, 51-56. [CrossRef]

85. Taghavikhalilbad, A.; Adabi, S.; Clayton, A.; Soltanizadeh, H.; Mehregan, D.; Avanaki, M. Semi-automated localization of dermal epidermal junction in optical coherence tomography images of skin. Appl. Opt. 2017, 56, 3116. [CrossRef]

86. O'Leary, S.; Fotouhi, A.; Turk, D.; Sriranga, P.; Rajabi-Estarabadi, A.; Nouri, K.; Daveluy, S.; Mehregan, D.; Nasiriavanaki, M. OCT image atlas of healthy skin on sun-exposed areas. Ski. Res. Technol. 2018, 24, 570-586. [CrossRef]

87. Mogensen, M.; Thrane, L.; Jorgensen, T.M.; Andersen, P.E.; Jemec, G.B. OCT imaging of skin cancer and other dermatological diseases. J. Biophotonics 2009, 2, 442-451. [CrossRef]

88. Goodson, A.G.; Grossman, D. Strategies for early melanoma detection: Approaches to the patient with nevi. J. Am. Acad. Dermatol. 2009, 60, 719-735. [CrossRef]

89. Menge, T.D.; Pellacani, G. Advances in noninvasive imaging of melanoma. Semin. Cutan. Med. Surg. 2016, 35, 18-24. [CrossRef]

90. Nischal, U.; Nischal, K.; Khopkar, U. Techniques of skin biopsy and practical considerations. J. Cutan. Aesthet. Surg. 2008, 1, 107-111. [CrossRef]

91. Boone, M.A.; Norrenberg, S.; Jemec, G.B.; Del Marmol, V. High-definition optical coherence tomography imaging of melanocytic lesions: A pilot study. Arch. Derm. Res. 2014, 306, 11-26. [CrossRef]

92. Gallwas, J.K.; Turk, L.; Stepp, H.; Mueller, S.; Ochsenkuehn, R.; Friese, K.; Dannecker, C. Optical coherence tomography for the diagnosis of cervical intraepithelial neoplasia. Lasers Surg. Med. 2011, 43, $206-212$. [CrossRef]

93. Adabi, S.; Turani, Z.; Fatemizadeh, E.; Clayton, A.; Nasiriavanaki, M. Optical Coherence Tomography Technology and Quality Improvement Methods for Optical Coherence Tomography Images of Skin: A Short Review. Biomed. Eng. Comput. Biol. 2017, 2017. [CrossRef]

94. Turani, Z.; Fatemizadeh, E.; Blumetti, T.; Daveluy, S.; Moraes, A.F.; Chen, W.; Mehregan, D.; Andersen, P.E.; Nasiriavanaki, M. Optical Radiomic Signatures Derived from Optical Coherence Tomography Images to Improve Identification of Melanoma. Cancer Res. 2019. [CrossRef]

95. Adabi, S.; Fotouhi, A.; Xu, Q.; Daveluy, S.; Mehregan, D.; Podoleanu, A.; Nasiriavanaki, M. An overview of methods to mitigate artifacts in optical coherence tomography imaging of the skin. Skin Res. Technol. 2017, 24, 265-273. [CrossRef]

96. Wang, L.V.; Hu, S. Photoacoustic tomography: In vivo imaging from organelles to organs. Science 2012, 335, 1458-1462. [CrossRef] 